\title{
Grounding practical normativity: going hybrid
}

\author{
Ruth Chang
}

Published online: 17 January 2013

(C) Springer Science+Business Media Dordrecht 2013

In virtue of what is something a reason for an agent to perform some action? In other words, what makes a consideration a reason for an agent to act?

This is a prima facie metaphysical or meta-normative question about the grounding of reasons for action and not a normative question about the circumstances or conditions under which, normatively speaking, one has a reason to do something. The normative question is answered by normative theory, as when one says that such-and-such feature of an action is a reason to perform that action because bringing about that feature would maximize happiness. The metaphysical question asks instead for the metaphysical determinant of something's being a reason. When we ask for the ground of a reason's normativity, we ask what metaphysically makes something have the action-guidingness of a reason: where does the normativity of a practical reason come from? As Christine Korsgaard puts it somewhat more poetically what is the 'source' of a reason's normativity?

This paper takes a synoptic approach to the question of source, and from this broad perspective explores the idea that the source of practical normativity might best be understood as a hybrid of more traditional views of source.

The paper begins with a survey of three leading non-hybrid answers to the question of a practical reason's normative ground or source (Sect. 1). It then recapitulates one or two of the supposedly most difficult problems for each, suggesting along the way a new objection to one of the leading views (Sect. 2). It ends with a sketch of an alternative, hybrid view about source-what I call 'hybrid voluntarism' - (Sect. 3) which, as it turns out, avoids each of the main problems faced by the three leading 'pure' views (Sect. 4).

Hybrid voluntarism grounds practical normativity in a structured relation of two sources, one of which is willing. The view that willing is a ground of normativity has not had many defenders because it is widely thought to suffer from two fatal

R. Chang $(\square)$

Department of Philosophy, Rutgers University, New Brunswick, NJ, USA

e-mail: ruthechang@gmail.com 
flaws. As we will see, however, by 'going hybrid' and making willing the ground of only some, but not all, of practical normativity, we avoid not only these fatal flaws but also what are arguably the most difficult problems for the other leading views. Unlike most hybrid theories, then, which inherit the central flaws of the views they combine, hybrid voluntarism cures the main flaws of its component views taken in their 'pure' form. The aim of this paper is not, however, to argue that the hybrid view is true-arguments for why hybrid voluntarism is an independently attractive view of the sources of normativity are undertaken elsewhere-but only to suggest that in thinking about the source of normativity, 'going hybrid' may well be the way to go. ${ }^{1}$

\section{Three views about normative source}

We should start by distinguishing the grounding question from others in the neighborhood. When we ask for the ground of something's being a reason, we are not asking what causes something to be normative, if indeed that question makes sense. We are looking for something deeper, for what metaphysically determines something's being a reason.

Nor are we asking for the subvening base of something's being a reason, that is, which facts modally covary with the fact that something has the action-guidingness of a reason. The source of normativity isn't what modally covaries with something's being a reason since the explanation provided by source is asymmetric. Consider the case of morality. Suppose God's will is the source of morality; God's commandsor a supernatural realm-is where morality comes from. While God's commands may modally covary with the moral facts, there is more to his being the source of these moral facts than simply modally covarying with them. God's commands explain the moral facts but are not explained by them. So the source of moral facts is one thing and their subvening base another.

A third question asks what general principle or law subsumes the fact that something is a reason. There is a sense in which the normativity of particular reasons may 'come from' more general normative principles, if the most extreme forms of particularism are mistaken. But when we wonder about the grounds of normativity, our question is not about the subsumption of particular reasons, such as that it hurts Jane, under general normative reasons or principles, such as that one shouldn't hurt others unnecessarily, but rather about one fact being the metaphysical fount of another.

Intuitively when we ask about the source of normativity, we are asking what 'makes' something normative, what it is 'in virtue of which' something has the normativity of a practical reason. For simplicity, we can assume that all reasons are facts and that their grounds are also facts. If we trace the normativity of a reason

\footnotetext{
${ }^{1}$ In other work I argue that hybrid voluntarism is needed to explain two puzzles of rational choice (Chang 2009), to make sense of the phenomenon of commitment in personal relationships (Chang 2013a), and to explain some special subclass of reasons we have to pursue personal projects [Chang (Manuscript)]. It also underwrites, I argue, the phenomenon of hard choices more generally (Chang 2012).
} 
back to its fount, we will reach what 'makes' that fact a reason in the first place-its metaphysical source or ground. ${ }^{2}$ For our purposes there is no need to engage the burgeoning literature on grounding relations; we can work with the basic idea that fact $\mathrm{y}$ grounds fact $\mathrm{x}$ when $\mathrm{y}$ gives a metaphysically necessary explanation of $\mathrm{x}$ that is not causation, modal covariation, or subsumption.

Now there is more than one way in which one fact can make something the case, different ways in which a fact can be grounded. The most natural way one fact can ground another is by constituting it, or, equivalently, by the one fact consisting in the other. The fact that $\mathrm{p}$ or the fact that $\mathrm{q}$ grounds the fact that $\mathrm{p}$ or $\mathrm{q}$ in that the former facts constitute the latter fact, and the latter fact consists in the former. The fact that it's $\mathrm{H}_{2} \mathrm{O}$ grounds the fact that it's water in that its being $\mathrm{H}_{2} \mathrm{O}$ constitutes its being water, and its being water consists in its being $\mathrm{H}_{2} \mathrm{O}$. Or consider causation. Striking a match causes it to light. What 'makes' the striking cause the lightingwhat constitutes the fact that the striking causes the lighting, in what does the fact of its lighting when struck consist? One answer might be 'a nomological law according to which under conditions $\mathrm{C}$, a striking of a match causes the match to light', and another might be 'a set of regularities whereby a striking of a match under conditions $\mathrm{C}$ is followed by its being lit'. This law, or this regularity, is what constitutes the fact that the striking causes the lighting. Tracing the causality back to its fount by discovering what constitutes something's having it, we end at the law or regularity.

So one way to answer the question, What is the source of $\mathrm{x}$ ? is by saying what constitutes the fact that $\mathrm{x}$. And thus one way of answering the source question about normativity is by saying what constitutes the fact that something is a reason.

Another way something can-perhaps degenerately-be grounded is by being 'self-grounded', that is, by being its own fount. Consider, again, the case of cause. If we ask, 'Where does a law that constitutes the fact that one event causes another come from?', the answer may be 'Nowhere' or, as I will treat as equivalent, 'From itself'. ${ }^{3}$ Or suppose we ask, 'Where does the negative charge of an electron come from?' The answer might be 'From the fact that an electron has a negative charge'; there's no more explanation to be had, end of story. Facts that are explanatorily primitive are self-grounded; they cannot be accounted for in any other terms and represent the end of the line in explanation. Hence, we might say, they are their own ground.

Thus another way to answer the source question is by appealing to the fact whose source we are seeking in the first place-the fact is its own source. If we ask where the normativity of a reason comes from, one possible answer is that the fact that something is a reason is, in a degenerate sense, its own source.

\footnotetext{
2 The idea of 'ground' was explicitly introduced into the contemporary scene by Kit Fine 2001. See also Rosen (2010).

3 Of course 'Nowhere' and 'From itself' are not in fact equivalent, but for the purposes of the present discussion, they can be treated as such. Externalists who baulk at the description of their views as ones in which certain normative facts are self-grounded can substitute 'ungrounded' for 'self-grounded' without any substantive loss in the subsequent argument of the paper. It is, I suspect, the externalist's insistence that there are no metaphysical grounds of normative facts that has helped to obscure the importance and legitimacy of the source question in the debate about practical reasons.
} 
There is, I believe, a third way in which one fact can intuitively 'make' or 'ground' another that is neither a case of constitution nor one of self-grounding, but since it is highly controversial, I mention it here only to raise the prospect of a further possibility. This is a relation of metaphysical creation or construction. Consider, again, the case of cause. The fact that the striking of the match causes the lighting may be constituted by a law of causation, but what is the source of this nomological law? Where does it come from? As we've already seen, one answer might be "Nowhere" - it is its own ground. But there is another possible answer. Perhaps God metaphysically creates the law of causation by commanding that it exist. What makes the fact that there is a law of causation is the fact that God willed such a law. Metaphysical creation is not creation in the ordinary, causal sense, as when you or I might create a sculpture. God does not cause the law of causation to come into existence in the way that an ordinary person might cause an artwork to come into being. For one thing, he is, by hypothesis, outside of the domain of the causal laws. For another, there doesn't seem to be enough of a gap between the event of God's commandment and the existence of the law for the case to be one of cause and effect. The law seems to come into existence by the command in some more direct way. Moreover, his command doesn't seem to constitute the law-the law is constituted, for example, by certain nomological necessities. Rather, God's command seems metaphysically to create the law without constituting it. (And if you don't like God, substitute the Big Bang).

Or consider the naming of your newborn. What makes it the case that your little bundle of joy is called 'Winston'? The fact that you have named him 'Winston'. The fact that he is called 'Winston' doesn't consist in the fact that you so named himrather, the fact that you so named him metaphysically creates the fact that his name is 'Winston'. Nor does your naming him 'Winston' cause the fact that his name is Winston-to be a case of cause, the effect must be distinct from the cause, but there doesn't seem to be enough distance between your dubbing him 'Winston' and the fact that his name is 'Winston' for the relation to be one of cause and effect. Nor must a naming convention be in place in order for his name to be what you dub it to be. You might be grow up alone on a deserted island and start calling a mysterious orange-colored ball that washes ashore 'Winston'. By calling it by that name, you metaphysically create the fact that its name is Winston.

Or, to take a final example, consider the way in which a law 'makes' or 'grounds' certain regularities. The law 'All crows are black' doesn't constitute the generality that all crows are black, nor does the generality consist in the law. And the law certainly doesn't cause the generality. Rather, the law that all crows are black metaphysically creates the generality that all crows are black. So, perhaps, another way to answer the question, 'What is the source of $x$ ?' is to say what metaphysically creates $\mathrm{x}$-whatever metaphysical creation turns out to be. ${ }^{4}$

\footnotetext{
4 To my knowledge, metaphysicians have not countenanced the possibility of metaphysical creation, and it may not be a genuine third way one fact can ground another but instead reduce to constitution. I don't believe it does but can offer no more than dogmatic assertion here. Nothing in what I says here turns on metaphysical creation being a distinct, third kind of grounding relation. Obviously, more needs to be said about each of these grounding relations, but my aim is simply to catalog those that are, I believe, relevant to understanding practical normativity.
} 
There are thus three ways in which the question, 'What makes something a reason for action?' can be answered. The fact that something is a reason can, degenerately, be its own ground or source; its ground can be what constitutes the fact that it is a reason; and finally, the source of a reason can be what metaphysically creates the fact that it is a reason.

Philosophers can be seen as having offered three main answers to the source question, each of which broadly corresponds to one of the three ways the source question can be answered. 'Source externalists' (e.g., Plato, Clark, Sidgwick, Prichard, Moore, David Ross, Dancy, Enoch, Nagel, Parfit, Raz, Scanlon, Shafer-Landau, Thomson, Wallace, and Wedgwood) think that normative facts make some fact, like the fact that it is painful, a reason. So the source of normativity is external normative facts. These facts are 'external' in the sense that they lie outside of us as agents.

Some source externalists think that the normative facts that ground the fact that something is a reason are those very facts; when we ask what 'makes' something a reason, our answer is 'nothing', or, equivalently for our purposes, 'the fact itself'. In this way, the fact that something is a reason is self-grounded. Put another way, when we contemplate the fact that something is a reason, we are already at the source of the normativity of that reason. ${ }^{5}$ Other source externalists think that the normative facts that ground the fact that something is a reason are other normative facts, facts not about reasons but about values, for example, evaluative facts about the goodness of things, where value is not simply a matter of being reason-providing. The constitutive ground of the fact that being painful is a reason to avoid it is the badness of the experience, and hence it is the disvalue of the experience that is the source of the reason's normativity. So the source of the normativity of your reason- 'it's painful!'- to avoid touching the hot poker is either the fact that its being painful is such a reason or the fact that pain is bad. ${ }^{6}$

While normative externalists can be said to locate the source of normativity outside of us, in a realm of normative facts, 'normative internalists' (e.g., Hume, Falk, early Foot, Williams, Railton, Brandt, Darwall, Manne, Markovits, Nichols, Michael Smith, Mark Schroeder, Tiberius, and probably Rawls) think normativity has its source inside of us, and in particular, in desires and dispositions - the mental states towards which we are largely passive. If the fact that an experience is painful gives you a reason to avoid it, it does so in virtue of the fact that you want-or would want under certain evaluatively neutral conditions - to avoid pain. What constitutes the fact that something is a reason is thus some relation between that thing and one's desires or dispositions. One way something might relate to your desires is by being constitutive of its satisfaction. Suppose you want pleasurable experiences. What constitutes the fact that being pleasurable is a reason for you to

\footnotetext{
${ }^{5}$ I mean to include here those source externalists like Raz (and implicitly Parfit and Scanlon), who constrain the fact that something is a reason by facts about rational agents so that something doesn't count as a reason unless it is the kind of thing that a rational agent could recognize and respond to. For an explicit discussion of this constraint, see Raz (2011, ch. 5).

${ }^{6}$ Some source externalists are pluralists, holding that sometimes the fact that something is a reason is self-grounded and sometimes it is constituted by an evaluative fact. See e.g., Raz (1999). What sort of externalist view one holds depends on one's views about the logical priority between values and reasons. If both are primitive normative phenomena one is likely to be a pluralist source externalist.
} 
pursue it? The fact that you want pleasure and that being pleasurable is constitutive of satisfaction of that desire. Another way something can relate to your desires is by being instrumental to its satisfaction. What constitutes the fact that being painful is a reason to avoid it? The fact that you want to concentrate on writing your paper, and the pain would be distracting.

Source externalism and internalism occupy the bulk of discourse about the source of normativity. Each appeals to one or other of the first two explanatory connections of grounding-self-grounding and constitution. Together they offer a neat dichotomy in thinking about normative source-it is grounded either in facts external to us or in our internal dispositions, desires, and motivations.

There is, however, a third view, what we might call 'source voluntarism'. According to voluntarism, normativity comes from an act of will. Like internalism, voluntarism locates the source of normativity inside of us-but not in passive states like desiring but rather in the active state of willing. Divine command theory offers the earliest example of such a view; by willing it, God can ground the fact that being a hoofed animal is a reason not to eat it. Post-enlightenment philosophers replaced God's will with our own; through an act of will, a rational agent can lay down laws for herself. A rational agent's own legislation can ground the fact that something is a reason. Kant's revolutionary account of normativity, at least as interpreted by some, is the most developed defense we have of voluntarism, but other voluntarists arguably include Dun Scotus, Hobbes, Locke, Pufendorf, and Fichte. ${ }^{8}$

An interesting feature of source voluntarism is that, unlike both source externalism and source internalism, voluntarism can in principle provide an answer to the source question via either constitution or metaphysical creation. An act of will can be the constitutive ground of something's being a reason and it can also be what creates, as opposed to constitutes, the fact that it is a reason. The fact that something is a reason could consist in the fact that God, or a rational agent, wills something; perhaps there is nothing more to being a reason than being willed by God or a rational agent. More strikingly, the fact that an agent wills something could metaphysically create the fact that something is a reason. By willing something, you may metaphysically create the fact that something is a reason in much the same way that by 'willing' your newborn to be called 'Winston', you metaphysically create the fact that his name is Winston. ${ }^{9}$

\footnotetext{
7 Source voluntarist views should be distinguished from the many normative views according to which an act of will—such as making a promise-can result in having reasons. This is the standard view about what role willing can play in practical normativity: there is some normative principle or value in virtue of which an act of will, such as promising, results in having a reason, such as to do what you promised to do. The idea that the normativity of willing is grounded in value in more or less direct or indirect ways traces back to Neil MacCormick (1972) and Joseph Raz (1972) (see also Raz 1975: Sect. 3.2). For some recent examples see e.g. Enoch 2011; Verbeek (Manuscript); Koch (2012). Christine Korsgaard, and perhaps Mary Clayton Coleman (Manuscript), are the only non-theistic contemporary philosophers I am aware of (besides myself) who think that willing can be a metaphysical ground of normativity.

${ }^{8}$ See Schneewind (1998).

9 Those who are attracted to source voluntarism but are skeptical of Korsgaard's claim that guidance by the Categorical Imperative is constitutive of action itself might find a defense of source voluntarism that takes the grounding relation to be one of metaphysical creation, not constitution. I try to offer such a defense in other work. See n.1.
} 
Exactly how source voluntarism is understood also depends on how 'willing' is understood. 'Willing' in contemporary parlance is usually taken to be a conscious deliberate decision to do something, as when you 'steel your will' and do something you don't want to do, or, as captain, 'willingly' go down with your ship. It might be thought to be nothing more than a kind of intention, caused by a normative belief about what one has most reason to do, as when one weighs up the pros and cons of two alternatives and finally 'wills' to do what one believes is supported by the most reason; it might be caused by a motivating desire as against such a belief, as in cases of weakness of will; or it might even be uncaused or at least a sui generis intentionlike state outside of the domain of causation.

But 'the will' is also sometimes taken to be shorthand for the agent herself and 'willing' correspondingly taken to be an activity constitutive of either rational agency or agency itself. You might consciously and deliberately decide or intend to exercise every day, but your will-your agency_is not cooperating. Willing is thus sometimes understood not as a conscious, deliberate decision to do something but as the activity of (rational) agency as such. Perhaps willing in this sense is what grounds the fact that something is a reason. Kant, by the lights of certain modern interpreters, had such a view: a will constrained by rationality is that in virtue of which something is a reason. ${ }^{10}$

Or we might understand willing as the activity of agency involved in putting yourself-your agency_behind something. By willing something, you give it your agential stamp of approval. And perhaps this agential stamp of approval can confer normativity. Indeed, as I'll be suggesting later, by willing something to be a reason-by putting your agency behind it as a reason-you can make or create the fact that it is a reason in something like the way your willing that the name of your newborn be 'Winston' makes or creates the fact that his name is Winston. Willingputting your agency behind a fact-I suggest, can be that in virtue of which that fact is a reason.

\section{Problems with externalism, internalism, and voluntarism}

Objections to the three standard views of source are familiar, and what follows is largely a potted survey of what is widely considered to be one or two of the most serious difficulties for each view. I say 'largely' because I want to suggest the outlines of a new objection to source externalism which, I suspect, may in the end prove to be more significant than the usual problems raised for the view. I won't have the space here to develop this objection in full, but hope to say enough to give its gist.

The usual objections to source externalist views are these. First, source externalism cannot explain how we come to be motivated by reasons or, a close relative, why we should do what we have reasons to do, if what makes something a reason is an external normative fact. In short, why should we care about some fact that is made a reason by some fact external to us? Second, familiar from Mackie,

${ }^{10}$ See Korsgaard (1996, 2008, 2009) for a development of this view. 
source externalism is encumbered with the metaphysical queerness of normative facts and the epistemological queerness of how we could come to know them. We should reject source externalism because it countenances nonnatural external normative facts.

These worries, however, seem to me respectively misguided or inflated. The first worry is met by pointing out that what it is to be rational is to recognize one's reasons and thereby be motivated to do what one has reason to do. And if being rational involves recognizing one's reasons and responding appropriately to them, then it makes little sense to ask how reasons can be authoritative for rational persons - that is, why a rational person should do what she has reasons to do. So the way in which reasons whose normative source is given by normative facts 'get a grip' on us is through our capacity for rationality.

The second worry gets its sting from the assumption that in order to be epistemically and metaphysically respectable, normativity must be a natural phenomenon. If normativity is a sui generis, nonnatural justificatory force, however, we shouldn't expect to come to know normative truths in the way we come to know natural truths or for normative properties to fit into the metaphysical mold of natural ones. This is not to deny that an explanation of how we come to know such truths and what are their natures is owed, but such an explanation is owed not just for normative truths, but presumably for modal, phenomenal, and mathematical ones too. And since it seems pretty clear that we know at least some normative, modal, phenomenal, and mathematical truths and have at least some grasp of their essential features, the problem of explaining how we come to know them and what they are like can be reasonably seen, as it were, a matter of detail and not itself grounds for rejecting the view. Mackie himself recognized that this problem of "partners in guilt' was the main weakness of his queerness arguments, but his response to it is unsatisfactory. The main point here, however, is that these queerness objections depend on substantive assumptions about the nature of reality-whether it must be natural-about which one should arguably, at least in the first instance, be neutral when trying to answer other substantive metaphysical questions, like that of the source of normativity.

\subsection{A problem with source externalism}

The main problem with source externalism, I suggest, is what we might call the Problem of Explanatory Shortfall. Source externalism can offer no explanation just where further explanation seems to be needed. This is not the familiar point that source externalism-like any other theory of source-must turn its spade somewhere. Nor is it the Korsgaardian complaint that source externalists refuse to answer 'the normative question', viz., 'What justifies the claims morality makes on us?' ${ }^{11}$ The worry is not that the externalist doesn't have a good answer to this question-he does for the most part—but that he hits bedrock in cases in which it is most plausible to suppose that there is more explanation to be had. This worry is most clearly formulated against the most widespread form of source externalism-

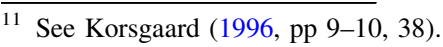


the self-grounded view_-but it can be extended to other forms of source externalism as well. ${ }^{12}$

Consider the fact that a certain consideration has a particular normative weight against other considerations in a particular set of circumstances. How is this fact to be explained? There are many cases in which the right thing to say will reasonably be: 'There is no more explanation to be had-that's just how thigns are'. In most circumstances, if you can save a drowning stranger at the cost of ruining your new shoes, the answer to the question, 'Why does the fact that the act would save her life have greater normative weight than the fact that it would ruin your shoes?' can reasonably be 'Those are just the normative facts.'

There are other cases - 'hard cases'-however, in which further explanationexplanation beyond 'that's just how things are'-is reasonably demanded, and the source externalist cannot provide it. This is because in at least some cases, the source externalist must hold that the fact that some reason is stronger or more significant than another is self-grounded-there is no further answer to the question, 'Why is this reason stronger than that one?' other than 'That's just how things are'. In hard cases, the normative relations among the reasons at stake is a highly nuanced and circumstance-sensitive matter, it is very unclear how to go about determining what those relations are, and the resolution of the case is of great importance. How much should you give to charity? Should you have one child, two, five, or none? Which of two careers should you pursue, all things considered-one in the arts or one in finance? Should you care for your family or serve your country? Marry Harry or Barry? And so on. These are the cases of interest to philosophers because of their importance to human lives and the epistemic challenge they pose. Much of firstorder normative theorizing is taken up with proposals as to why the normative relations in hard cases such as these are one way rather than another.

Now it is a fact about hard cases that people can reasonably differ about how such cases should be resolved. Some might reasonably believe that you have most reason to $\mathrm{x}$ while others reasonably believe that you have most reason to not- $\mathrm{x}$, or they might reasonably disagree in other ways. If source externalism is not to be completely anodyne, claiming only that what we have most reason to do is whatever reasonable people agree we have most reason to do, it will sometimes claim that we have most reason to $\mathrm{x}$ when at least some reasonable people believe we have most reason to not-x. Suppose that Jane is deciding between a career in painting and one on Wall Street. Suppose too that the case is hard-reasonable people differ about what Jane has most reason to do. Finally, suppose that the Jane reasonably believes that she has most reason to be a painter, but the normative facts are that she has most reason to be a banker.

\footnotetext{
12 Strictly speaking, there are forms of source externalism for which this problem does not arise, but they are all ones in which hard cases never arise. For example, source externalist theories that think all values or reasons can be represented by some function over the reals that is easy to manipulate (e.g. involving only addition or multiplication) would always deliver a determinate answer as to what one has most reason to do and would preclude hard cases. But since it is clear that there are hard cases, such theories are substantively implausible. I assume such views should be rejected on other grounds and do not discuss them here.
} 
Jane believes she has most reason to spend her life as an artist but the externalist tells her that she has most reason to spend her life as a banker. Jane is puzzled. Why does she have most reason to spend her life on Wall Street? The need for further explanation here is acute, but all the externalist can say is: 'These are the normative facts: you have most reason to spend your life on Wall Street and that's just how things are. We have hit rock-bottom and there is no more explanation to be had.' Of course not all hard cases need be ones in which we have hit rock bottom, but source externalists must hold that some are, and for those that are, we will have run out of explanation just where it is most needed.

It might be thought that, although the source externalist cannot give a direct explanation of why we have most reason to $\mathrm{x}$ though we might reasonably believe we have most reason to not-x, she can give an 'indirect' explanation. She might indirectly explain why we have most reason to $\mathrm{x}$ in a given hard case by pointing out how those reasons and similar ones relate in other cases. Instead of saying to Jane 'That's just how things are', she might say 'That's just how things are, and you can see why they are that way by looking at how the reasons relate in these other cases.' And this indirect explanation, though not as good as a direct one, is good enough; it is all that can be reasonably expected in such hard cases. So perhaps there is no explanatory shortfall after all.

This strategy, however, is problematic because it is doubtful that all hard cases are amenable to indirect explanation. In attempting to give an indirect explanation as to why Jane has most reason to be a banker, the source externalist will need to appeal to general normative considerations, such as principles, aims, policies, values, and the like, which provide the normative relations of the reasons relevant in the case and other related ones across a range of cases. But general considerations are by their nature general and don't deliver answers as to what one has most reason to do in every possible circumstance. Take the principle 'You should aid victims of harm unless the cost is too high'. Such a principle can indirectly explain why you have most reason to save a drowning stranger when the cost is your shoes or your coat or your laptop_all easy cases_but can't plausibly explain, indirectly or otherwise, why you have most reason to save the stranger, assuming that you do, when the cost is your leg or your life's work or the life of a severely disabled person-all hard cases. Which costs are 'too high'? The general principle doesn't tell us. Hard cases are very plausibly those that fall between the boundaries of straightforward application of general, abstract principles and so their resolution cannot be explained by those principles. Indeed, as the casuistic work of Frances Kamm and others suggests, general principles are refined and their application extended by piecemeal resolution of hard cases. The relation among reasons in hard cases thus explains and is not explained by general principles. Jane is again left without an explanation.

Now the source externalist could turn instead to very specific and detailed 'principles' that determine what one has most reason to do every hard case in which one has most reason to do something. These wouldn't be principles of the ordinary kind because so specific, and since they cover every case, each might be thought of as a chapter of the Book of Reasons, with each chapter laying out the way some subset of reasons relate to one another in every possible circumstance. It is unlikely 
that we could grasp any such 'principles', but the externalist might nevertheless vaguely point to such 'principles' as providing an indirect explanation as to why one has most reason to $\mathrm{x}$ in a given case. That we can't grasp them is a deficiency in us, not in the explanation they provide.

But a 'principle' laying out how every subset of reasons relates in every circumstance is highly implausible as a brute normative truth. What's more plausible is that this 'principle' gets its content at least in part via more specific truths of the form 'in such-and-such hard case, the reasons relate in such-and such a way.' The relations among reasons in hard cases seem explanatorily prior to any 'principle' laying out how reasons relate across all circumstances. And so the Problem of Explanatory Shortfall remains.

Other forms of externalism seem vulnerable to the same worry. Consider, for example, an externalist who locates the source of normativity not in the fact that something is a reason but in an evaluative fact, such as the fact that doing something while being motivated by a certain consideration is valuable in some way. While values seem have more explanatory power than the normative fact that something is a reason, it is nevertheless hard to believe that values can explain, directly or indirectly, why reasons have the weights that they do in hard cases. Like principles, values are by their very nature general and law-like; they don't have fully determinate structures from which relations among the specific reasons to which they give rise can be 'read-off' in every possible set of circumstances.

The need for an explanation in hard cases is especially acute. That is part of what makes them 'hard'; we need to understand why they are resolved in the way they are because what is at stake is significant, and yet there is no easy explanation as to why their reasons relate as they do. In hard cases, it is wholly unsatisfying to rest with 'That's just how things are'. Source externalism is arguably committed to saying that in at least some such cases, there is no further explanation to be had. The scope of the problem, of course, depends on the depth and extent of hard cases for which this is true, but there is no a priori reason to think that the problem is of limited scope.

\subsection{A problem with source internalism}

The main difficulty with source internalism has been forcefully pressed by Derek Parfit in his magisterial On What Matters. Source internalism fails to guarantee the right substantive results about what reasons we have because the constraints it puts on desires are purely formal in nature. No formal constraint, however intricate, can guarantee the intuitively right answer as to what reasons we have. If what makes something a reason is some formal relation with our desires and dispositions then, given the right desires, it could turn out that an agent has most reason to want agony-an intensely disliked sensation-for its own sake because having such a desire satisfies other desires the agent has. ${ }^{13}$ But, the agony argument goes, everyone has a reason not to want agony for its own sake, even if agony is what she most wants or wanting agony would satisfy other desires she has. For the most part,

\footnotetext{
13 Parfit has many arguments against the source internalist, but I present what I take to be the strongest argument in its strongest form. See Parfit (2011).
} 
the various ingenious ways that source internalists have tried to deliver reasons not to want agony for its own sake either fail on their own merits or end up smuggling substantive constraints that presuppose normative resources beyond what the internalist can legitimately help herself to. ${ }^{14}$ Call this the Right Reasons Problem.

Internalists have responded to this problem in two ways. Some are happy to bite the bullet and allow the admittedly untoward result that someone can have most reason to want agony for its own sake. But they are happy to do this either because they think such a person is an outlier, and a theory shouldn't be too concerned if it can't cover outlier cases, or because they think that this admittedly unfortunate consequence is outweighed by one of internalism's main attractions: naturalism about the normative. ${ }^{15}$ But appealing to the fact that we are unlikely to encounter what is admittedly a counterexample to the theory in our own world, such as it contingently is, is a bit like a hedonistic act utilitarian brushing off counterexamples to his theory by protesting that the situations in which pleasure would be maximized by, say, punishing an innocent person will in fact be rare. It amounts to sweeping the problem under the rug. And, as we've already suggested, it is methodologically unsound to let prejudices about whether everything is natural decide other substantive debates, since these should be evaluated on their own merits. If a theory suffers from a serious substantive flaw, pointing out that it nevertheless preserves a naturalistic metaphysics does nothing to erase or diminish that flaw. This would be like the analytic hedonistic utilitarian protesting in the face of counterexamples, 'So what? My theory doesn't deliver the right reasons but it guarantees naturalism about the normative!'. Metaphysical prejudices should not be allowed to corrupt substantive debate over the Right Reasons Problem.

Other source internalists deny that what needs biting is a bullet: it is perfectly acceptable to think that agents with certain desires, where these are had in a cool moment, survive cognitive psychotherapy-in short, pass whatever formal tests that have been devised for being rational- have a reason to want agony for its own sake since agents with such desires would be so different from us that any intuitive qualms we might have would depend on importing false assumptions about them. While some internalists fall back on this thought, none has yet provided any explanation of how our intuitions supposedly go awry or are unreliable in such cases. ${ }^{16}$ It seems there could be a recognizably human agent who has a strong intrinsic desire to be in agony for the next $30 \mathrm{~s}$ and who passes purely formal tests of

\footnotetext{
14 See Parfit (2011) for an argumentative tour de force against internalist accounts. The most impressive and detailed reply on behalf of source internalism, I believe, is found in forthcoming work by Peter Railton, who attempts to extract normativity from a psychologically nuanced account of desire that is tied to affect and reward. Railton's view arguably avoids falling prey to the most powerful arguments against internalism and succeeds in wringing from purely naturalistic materials a kind of normativity from a complex but psychologically plausible account of our desires. If Railton's view is viable, then the real issue may lie in whether the normativity the internalist can deliver is the normativity of reasons.

15 See most recently, e.g., Street (2009). Another putative attraction of source internalism is its easy ability to account for the necessary link between having a reason and being motivated to do what one has a reason to do and between believing one has a reason and being motivated to do what one believes one has a reason to do. But as we have seen the source externalist can also secure this link.

16 Attempts to debunk the intuition that no one has such reasons have not had unqualified success. Marcello Antosh (Rutgers, Ph.D. dissertation) is developing an interesting debunking line of argument on behalf of source internalists which draws on a range of empirical data.
} 
full information, imagination, understanding and the like. ${ }^{17}$ And it seems perfectly in order for us to insist, upon careful reflection, that such an agent has no reason to pursue the agony. If there is an error in our judgment, it remains to be identified. ${ }^{18}$

\subsection{Two problems with voluntarism}

Voluntarism is widely supposed to suffer from two fatal flaws. ${ }^{19}$ First, if what makes a consideration a reason is some act of willing, what prevents us from willing reasons willy-nilly? This was Samuel Clarke's attack against Hobbes's voluntarism and more recently Jerry Cohen's attack against the Kant-inspired voluntarism of Christine Korsgaard. As Cohen put the point, voluntarists cannot block a Mafioso's willing allthings-considered reasons to shoot the kneecaps off his rival. ${ }^{20}$ This is a version of the Right Reasons Problem already encountered. Kant's answer was that rational agents could not will reasons willy-nilly; rational agents are bound by purely formal laws that govern the autonomous, rational will, and these laws guarantee that a rational agent can will reasons only in accord with the moral law. But Kant's argument notoriously fails, and ingenious attempts to rescue Kant on this score have fallen short of the mark.

There is a second, related difficulty. Voluntarists try to constrain willing by appealing to what the rational agent must will in order to be a rational agent in the first place. The strongest sense of 'must' they are in the ballpark of defending, however, is only the 'must' of structural-or what is sometimes misleadingly called 'subjective' - rationality. So willing is a source of normativity that is constrained by structural requirements of consistency and coherence on attitudes. But now we can ask, Why should the rational agent be bound by such structural requirements? This question asks what reason an agent has to bind her will in this way. ${ }^{21}$ And this appeal to a reason requires further normative materials beyond those that the voluntarist is plausibly able to provide. Either the voluntarist must admit that her reason to follow structural requirements has its source in something other than structural requirements and so willing is not the only source of normativity, or she is faced with an unhappy endless regress of structural requirements that provide reasons to conform to other

\footnotetext{
17 Some Kantians make a similar maneuver, claiming that putative counterexamples to their theory involve outliers who are so different from us that we cannot confidently judge whether they are rational (see, for example, Hill 1991, chapter 4). The challenge to them is the same: why think such creatures are so different from us that we are unable to judge whether they have reasons to pursue agony for its own sake?

18 I offer a diagnosis of why source internalists find the Right Reasons Objection untroubling in Chang 2013 b.

19 Christine Korsgaard has done the most in contemporary times to revive the view, and I suspect that she has developed the view pretty much as elegantly, forcefully and plausibly as it can be (see Korsgaard 1996, 2008, 2009).

${ }^{20}$ Notice that the objection is not that the voluntarist cannot block the Mafioso from willing $a$ reason to harm his enemy. As I will suggest below, it is plausible to think that the Mafioso who wills a reason to harm his enemy has more reason to harm him than the Mafioso who doesn't, even though both have allthings-considered most reason not to do so.

21 Some have argued that there are no reasons to obey rational requirements (Kolodny 2005) or that there are no rational requirements as distinct from ordinary reasons (Raz 2005). But the Regress Problem turns on the intelligibility of asking for reasons to be prima facie structurally rational, whether or not at the end of the day there are any reasons to be or whether there are any structural requirements of rationality.
} 
structural requirements. In short, willing cannot be the source of normativity because it leaves open the question, What reason do we have to will in conformity with the requirements of structural rationality? Call this The Regress Problem. ${ }^{22}$

Modern-day voluntarists have tried to respond to this difficulty by suggesting that it is constitutive of agency that one's will conform to certain requirements. Korsgaard has ingeniously suggested that the principles willed by a rational agent are those that solve a practical problem the agent actually confronts. That is, the principles that a rational agent 'must' will are those that provide an answer to a practical problem to which she needs to have a solution. Thus, insofar as she is to be a rational agent in response to the practical problem she faces, she must will certain principles rather than others. Those principles provide a solution to her problem, so of course she 'must' will them if she is to respond to her problem as a rational agent. ${ }^{23}$ But as William Fitzpatrick has carefully argued, the 'must' her arguments deliver fall short of the 'must' of being an agent at all. ${ }^{24}$ Instead, Korsgaard at best shows that in order to conform to the requirements of structural rationality - to be a structurally rational agent - an agent 'must' will certain principles and not others. And since it makes sense to ask, Why be structurally rational?, the problem remains.

More recently, Korsgaard has developed her constitutivist argument by focusing on the metaphysics of action. You can't act unless your will is guided by the Categorical Imperative, among other principles. This is not to say that your will must conform to the requirements in order to act at all but only that it must conform to them if you are to act well. But you won't even count as acting unless what you're doing is guided by these requirements. ${ }^{25}$ Korsgaard's argument here is complex and provocative but, I believe, the fundamental problem remains. The essential difficulty is that our concept of a reason is not beholden to action or agency - it permits us to reach beyond action or agency to ask, 'Why act?' Korsgaard tells us that we can't help but act because acting is in our natures, but this does not stop the reasons question from rearing its inquiring head. Consider an analogy. Perhaps Rousseau was right: we can't help but make invidious discriminations among people because invidious discrimination is in our natures. But this does not block the question, What reasons there are for us to make such discriminations? In the same way, even if we can't help but act, we can still ask, Why act? Insofar as the question makes sense, the Regress Problem remains.

\section{Hybrid voluntarism}

Source externalism and source internalism occupy the bulk of both contemporary and historical debate about the source of normativity, despite their known

\footnotetext{
22 This objection is formulated in general terms by Railton (2004) and specifically against Korsgaard's voluntarism by Scanlon (2003) and Fitzpatrick (2005) and in a related form by Enoch (2006). But it goes all the way back at least to Clarke (1706/1969), and in the epistemic case to Ryle (1949).

23 Korsgaard (2003).

24 Fitzpatrick (2005).

25 Korsgaard (2009); see also Mary Clayton Coleman (Manuscript) who argues that guidance by prudential principles is constitutive of action.
} 
difficulties. Normativity either comes from outside of us, from a realm of normative facts, or from inside us, from passive states such as desires, dispositions, and motivations we have or would have under certain evaluatively neutral conditions.

That the debate about source has long had this focus-with voluntarism getting short shrift—seems to me unfortunate. The most profound-and interesting-divide in the debate is not between those who think normativity derives from normative facts (externalists) on the one hand, and those who think that it derives from a relation with our desires (internalists), on the other, but rather between those who think that normativity is given to us, either by normative facts or relations to passive states, like desires (externalists and internalists), on the one hand, and those who think that we can create it (voluntarists), on the other. Is normativity given to us or do we make it?

Hybrid voluntarism offers a way of understanding how these two fundamentally opposed approaches to the source of normativity - each boasting a persistent history of endorsement by distinguished thinkers - could each contain an important truth. If hybrid voluntarism is correct, sometimes the fact that a consideration has the normativity of a reason is given to us, while other times it is a fact of our own making.

Unlike the traditional views about source, hybrid voluntarism maintains that there is no univocal answer the question, What metaphysically makes a fact have the normativity of a reason? Sometimes the fact that a consideration is a reason is given to us and sometimes it is of our own making.

The hybrid view crucially turns on a distinction between two kinds of reasons: 'given' reasons, on the one hand, and 'will-based', or 'voluntarist', ones, on the other. 'Given' reasons are considerations that are reasons in virtue of something that is not a matter of our own making. They are given to us and not created by us and thus are a matter of recognition or discovery of something independent of our own volition or agency. Both source externalism and source internalism might best be understood as accounts of our given reasons: our given reasons might be 'valuebased' or 'desire-based': that in virtue of which they are reasons is either a normative fact or some relation to our desires or dispositions. My own preferred view, for reasons that will become apparent later, is to understand 'given' reasons as being grounded in normative facts rather than desires. 'Will-based' reasons, by contrast, are considerations that are reasons in virtue of some act of will; they are a matter of our creation. They are voluntarist in their normative source. In short, we create will-based reasons and receive given ones.

While standard forms of voluntarism hold that all reasons are will-based, hybrid voluntarism maintains that not all of our reasons are a matter of acts of will. Like traditional views about source, however, the hybrid view holds that each reason has a single normative source, and in this way, although it is pluralist about the sources of normativity writ large, it is univocal about the source of the normativity of each reason. ${ }^{26}$ Hybrid voluntarism's pluralism about normative source is not, moreover,

\footnotetext{
${ }^{26}$ No hay need to be made over the claim that given and voluntarist reasons are of different 'kinds'. Implicit in the view is a principle of the individuation of reasons according to which reasons are individuated not only by their contents but also by their normative source, and whether we want to classify reasons with different sources as different kinds of reasons is unimportant. This principle of individuation should not be too controversial. Consider a rough-and-ready analogy from physics. Just as a
} 
one of coeval considerations each taking turns being that in virtue of which a reason has its action-guiding force. The sources of normativity are structured. In answer to the question, 'What is the source of normativity?' hybrid voluntarism answers that the source of normativity is a structured hybrid of two sorts of consideration, sometimes given to us and sometimes of our own making. This structure has two aspects.

Most importantly, given reasons operate as metaphysical constraints on voluntarist ones; we cannot bring voluntarist reasons into existence unless our given reasons fail fully to determine what we should do. Given reasons have, as it were, 'first dibs' in determining what we should do. As I will put it, we can create will-based reasons only when our given reasons have 'run out'. 27

Reasons run out when they fail fully to determine what one has most reason to do. More precisely, they run out when (1) one fails to have more, less, or equal reason to choose one alternative over the other-what we might call a state of 'equipoise', or (2) one has most reason to choose one alternative over the other but it is indeterminate how much more-what we might call a state of 'indeterminate most reason'. Alternatives are in equipoise when they are incomparable or 'on a par'-that is, comparable, but neither is better than the other and nor are they equally good. ${ }^{28}$ And one alternative is supported by indeterminate most reason if there is more reason to choose it, but it is indeterminate what the overall normative difference is between it and its alternative. That is, one alternative is better, but to an indeterminate degree-it is this indeterminateness that precludes 'full determination' by one's reasons. ${ }^{29}$ With respect to ordinary given reasons, the latter condition is plausibly very common. And as I have argued elsewhere, so is the former. ${ }^{30}$

\section{Footnote 26 continued}

single object can exert different physical forces that are distinguished by the 'source' of that force-for example, gravitational or electromagnetic - a single consideration can count in favor of action in different ways - be the contents of different reasons - in virtue of having different normative sources. Compare Scanlon (2004), who rightly worries about a "puzzling duality" that may arise if a single reason can have two sources.

27 As Raz might say, reasons render options "eligible" (Raz 1999, p. 65). My claims are that (1) eligibility should be understood as leaving open the possibility of there being further will-based reasons, and (2) there are very specific ways in which the options can relate to one another in order to be "eligible" in Raz' sense, none of which are the ways Raz himself suggests, i.e., that the options are "incommensurable". This paper is part of a series of papers that attempt to defend (1), and I have tried to defend (2) in Chang 2002 and 2012.

28 See Chang 2002.

29 It may seem odd to say that reasons 'run out' when they determine what one has most reason to do but to an indeterminate degree, after all, they determine what one has most reason to do. But they 'run out' in the sense of interest-the normative criteria at stake do not admit of fully determinate measurement of degrees of difference. See Parfit (Manuscript) for further thoughts along these lines. Some normative criteria—such as number of lives saved-arguably allow fully determinate measurement of degrees of difference-e.g., saving two lives may be twice as good as saving one-and where such normative criteria, if there are any, are at stake, voluntarist reasons have no place. My own view is that there are few, if any normative considerations that admit of either ratio or interval cardinal measurement, but if it turns out that all do-if standard expected utility models of value are true to the facts and not mere idealizations - then hybrid voluntarism has no application.

30 There are, I believe, good reasons to think that voluntarist reasons can be created in the case of equipoise only when items are 'on a par' and not when they are incomparable, but defending that claim would take us too far afield. Some thoughts along these lines are in Chang 2012. 
According to hybrid voluntarism, the scope of normativity grounded in our wills is a direct function of the scope of equipoise and indeterminate most reason. This scope is plausibly both very wide - covering a wide range of choices — and very deepcovering some of the most important choices we might make.

Our given reasons, however, determine not only when voluntarist reasons can be created but also what role such reasons can play in determining what we should do. They operate not only as metaphysical constraints but also as normative ones. Whenever our given reasons have a valence, that is, whenever they determine that we have most reason to do one thing rather than another, our voluntarist reasons cannot alter that valence in the all-things-considered truth about what we have most reason to do; they cannot make it the case that the disfavored alternative is now better supported by reasons, nor can they make it the case that the alternatives are equally good or in equipoise. All they can do is change the degree or extent to which the favored alternative is supported by most reason.

Why these constraints? One answer is that, as we will shortly see, the structured relation among given and voluntarist reasons allows hybrid voluntarism to avoid the fatal flaws of 'pure' voluntarist views. But there is a deeper answer. The metaphysical and normative constraints on voluntarist reasons derive from an independently attractive, plausible view about the role of our agency in the world. Metaphysically speaking, if we have the freedom to create reasons, we have it only within the confines of the reasons we have no freedom to create, our given reasons. So we can create reasons only when our given reasons run out. Normatively speaking, just as our freedom to change the nonnormative facts of the world is constrained by the nonnormative facts given to us-we can't change the fact that there is a wall in front of us-so too our freedom to change the normative facts of the world is constrained by the normative facts given to us-we can't make ourselves have most reason $\mathrm{x}$ if the normative facts given to us are that we have most reason not to $\mathrm{x}$. The valence of given reasons is a non-negotiable wall around which we must exercise our agency.

If hybrid voluntarism is right, willing has an important, though constrained, role to play in determining what we have most reason to do. If you have most indeterminate given reason to $\mathrm{x}$ but will yourself a voluntarist reason not to $\mathrm{x}$, you may now have more reason not to $\mathrm{x}$ than you had before you willed yourself a reason to $\mathrm{x}$. In this way, through an exercise of your will, you can create reasons for yourself, thereby giving yourself more reason than you had before, though the normative upshot of those reasons is constrained by the valence of your given reasons. ${ }^{31}$ If, instead, your given reasons are in equipoise-if there is no valence to be disrupted - then through an exercise of your will, you can make it the case that you have most all-things-considered-given and voluntarist-reason to choose one alternative over the other. In this way, by willing yourself a voluntarist reason, you can directly determine what you have most reason to do.

\footnotetext{
31 Some might find the idea that the Mafioso has more reason to harm his enemy simply by willing problematic, but having 'a reason' is a relatively cheap matter, especially if that reason can never make it the case that he has all-things-considered reasons to harm his enemy. As those who have pressed the Right Reasons problem most forcefully have noted, the real problem arises when a view leads to the result that he has most all-things-considered reasons to harm his enemy.
} 
Here is an example. Suppose your boss gives you a holiday bonus, and as the circumstances have it, you can either donate it to Oxfam or buy yourself a new laptop. The case can be filled out in one of two ways. You might have most given reason to donate the money to Oxfam. In this case, you can, according to hybrid voluntarism, will yourself a reason to buy the laptop.

Now part of the plausibility of your being able to will yourself a voluntarist reason turns on what it is involved in so willing. This is just one of many details of hybrid voluntarism that cannot be adequately described here, so a gloss will have to do. Unlike many other voluntarist views, hybrid voluntarism maintains that what you will is itself normative: you will some consideration to be a reason. This willing a consideration to be a reason is not simply deciding, or believing, or wishing, or wanting it to be a reason; it is akin to a stipulation that something be a reason in much the way that you might 'stipulate' that your newborn be called 'Winston'. But when you will something to be a reason, something further beyond mere stipulation is involved: your agency is implicated. Very roughly, when you will something to be a reason, you put yourself behind some consideration that, as a logical matter, counts in favor of one of the alternatives. ${ }^{32}$ You take an agential stand of the sort: 'Having a few extra seconds of speed on my computer matters to me!' When you will yourself a voluntarist reason, you will a consideration, such as having a few extra seconds of speed, to be reason-providing for you. Having willed such a voluntarist reason, the difference in strength of the reasons to give the money to Oxfam and the reasons to buy the laptop will be less than it would have been had you not so willed. But this does not change the fact that what you should do is to give the money to Oxfam.

The case can be filled out in another way. Perhaps the given reasons to donate to Oxfam or to buy a new computer are in equipoise: the reasons for donating and for buying the laptop are neither stronger than one another and nor are they equally strong. By willing the extra speed of a new laptop to be a reason for you to buy one, you can create a voluntarist reason to buy the laptop and perhaps thereby give yourself most all-things-considered reason to do so. Whether you do have most reason to do so depends on the substantive question of how the voluntarist reason relates to the given reasons.

My aim here is not to lay out the full details of the view but only to say enough so that we are in a position to answer the question that is the focus of the paper: how does hybrid voluntarism avoid the main difficulties associated with each of the 'pure' views about normative source? To this we now turn.

\section{How hybrid voluntarism avoids the problem of explanatory shortfall, the right reasons problem, and the problem of regress}

Recall that in hard cases, the need for an explanation of the resolution is especially acute and it won't do to rest with 'That's just how things are'. Source externalism is,

\footnotetext{
${ }^{32}$ If I'm choosing between two desserts and what matters in the choice is tastiness, the fact that I'm wearing red shoes does not, as a logical matter in most normal circumstances, count in favor of one dessert or the other.
} 
I have suggested, committed to saying that in at least some such cases, there is no further explanation to be had.

If, however, as hybrid voluntarism might suppose, externalism accounts for the source of only some and not all of our reasons-if it accounts for the normative source of only our given reasons - then we can cure the Problem of Explanatory Shortfall by understanding externalism as a partial theory of source. Source externalism goes only so far providing reasons in normative explanation, leaving a gap that voluntarist reasons can fill. ${ }^{33}$

Hard cases are ones in which reasonable people can differ as to what one has most reason to do. This reasonable disagreement may at least sometimes indicate that the given reasons are in equipoise. If the given reasons are in equipoise, then individual agents are free to create voluntarist reasons that may make it the case that for that agent, she has most all-things-considered reasons to choose one way rather than another. This freedom to create voluntarist reasons when given reasons are in equipoise can explain both why reasonable people disagree about what one has most reason to do in hard cases and why one might nevertheless have all-thingsconsidered most reason to choose one way rather than another.

Return to the case of Jane. Reasonable people disagree about whether she has most reason to be a painter or a banker. The hybrid voluntarist can explain this reasonable disagreement as follows: The given reasons for pursuing one career over the other are in equipoise. When one person reasonably insists that Jane has most reason to be banker, this is because that person is putting himself in Jane's shoes and were he Jane, he would will some feature of the banking career to be normative for him. When someone disagrees, maintaining that Jane has most reason to be a painter, he again puts himself in Jane's shoes, and were he Jane, he would will some feature of being a painter as normative for him. One person says, 'Were I Jane, I would have most reason to be a banker', while the other says 'Were I Jane, I would have most reason to be a painter'. This is one way to understand disagreements about what career Jane has most reason to pursue, or for that matter, about whether one should give to Oxfam or buy a new laptop, help one's ailing relative rather than fight in the war, give up one's son rather than one's daughter to the cruel Nazi, or spend one's free time gardening or working on a political campaign, and so on. The source externalist, by contrast, cannot allow for reasonable disagreement. Instead, he would have to explain away the appearance of reasonable disagreement by insisting, for example, that at least one party is making an epistemic mistake. But we can imagine cases in which there is no reason to think that one party to the disagreement is epistemically less well-placed than the other.

\footnotetext{
33 This gap in externalist reasons is not, strictly speaking, only in hard cases or ones in which the given reasons are in equipoise. For even easy cases might involve voluntarist reasons. It might be obviously true that I have most indeterminate reason to save 5 lives at the cost of my new shoes. But there might be a difference in the relations among the reasons in the case in which I have willed the importance of those lives to be reasons for me and the case in which I have not. Nor should willing reasons be thought to be something that happens only after we are stymied by our given reasons. We are willing reasons-putting our agency behind certain considerations - all the time and succeed in giving ourselves voluntarist reasons when the given reasons have run out. The priority of given over voluntarist reasons is metaphysical and normative but not temporal.
} 
The hybrid voluntarist can explain why Jane has most all-things-considered reasons to be a banker. The externalist, recall, has to settle with 'That's just how things are' because we have hit bedrock. The hybridist maintains that Jane has most reason to be a banker because the given reasons are in equipoise, and Jane has willed a voluntarist reason in favor of banking. We can explain why Jane has most reason by appealing to the voluntarist reasons she has created as a matter of will. Thus hard cases are typically ones in which one's given reasons are in equipoise, and insofar as one has most reason to choose one option over the other, it is because one has voluntarist reasons that fill the gap left by one's given reasons.

Now in the case we imagined, Jane herself believes that she has most reason to be a painter even though she in fact has most all-things-considered-given and voluntarist-reasons to be a banker. But the hybrid voluntarist claims that Jane has willed herself a voluntarist reason to be a banker. How can this be? What this case shows that one's will need not line up with one's beliefs. Putting yourself behind a consideration in favor of banking need not be a conscious, deliberate activity that flows from your self-conception, or what Korsgaard calls your 'practical identity'. You can be sorely self-deceived about what matters to you. Jane, for instance, might conceive of herself as an iconoclastic free spirit, but, in fact, in cases in which the given reasons have run out her voluntarist reasons show that what she stands forwhat matters to her-are financial security and conventional measures of success. And in the present case, it may be that Jane has willed a life of financial security to be a reason for her to pursue the banking career in spite of her belief that she has allthings-considered reasons to be a painter. She is so caught up with her self-image as an artiste that she does not recognize that she has put her agency behind financial security as normative for her.

Obviously more needs to be said about what is involved in willing something to be a reason, but the point here is simply that the hybrid voluntarist can offer an explanation to Jane, despite her belief to the contrary, as to why she has most reason to be a banker. She has most reason to be a banker because her given reasons are in equipoise, and she has created a voluntarist reason in favor of banking. ${ }^{34}$ The story the hybrid voluntarist then goes on to tell is a richly normative and psychological one that goes well beyond the simple externalist response: 'That's just how things are'.

Now some hard cases might be ones in which there is most reason to choose one alternative over another but the given reasons are not in equipoise. ${ }^{35}$ In these cases, the given reasons determine that one has most reason to choose one way rather than another. Perhaps Jane has most given reason to be a banker and thus the answer as to why she has most reason to do so is 'That's just how things are'. So it might seem that even the hybrid voluntarist is left with the Problem of Explanatory Shortfall, albeit in a more restricted set of cases.

\footnotetext{
34 The phenomenology of choice lends some support to the hybrid voluntarist view. Empirical psychologists have suggested that in hard choices decision-makers often 'construct' reasons in order to resolve conflict. See Shafir et al. (1993).

35 I doubt there are many such cases because of the arguments mooted in Chang 2002 — hard cases are more often than not cases of parity.
} 
But hybrid voluntarists need never rest with 'That's just how things are' in a hard case because voluntarist reasons are in play even when one has (indeterminate) most given reason to do one thing rather than another. ${ }^{36}$ If Jane wills a voluntarist reason in favor of banking, the fact that she has most all-things-considered reasons to be a banker can be explained by both her given and voluntarist reasons to take up that career. If, alternatively, she wills a voluntarist reason in favor of the visual arts, that reason will be part of the story as to why she has most reason to be a banker. It is informative to be told that despite having a voluntarist reason in favor of a career in painting, one has most all-things-considered reasons to be a banker. This is because 'That's just how things are' is a fully passive explanation of why we have the reasons we do while appeal to voluntarist reasons, even if they can't change the valence of our given reasons, introduces our agency into the explanation. By appealing to reasons the agent actively puts herself behind, we no longer rest with reasons passively given to us - the explanation of why we have most reason to do what we have most reason to do always involves appeal to something other than the normative facts simply given to us. That is enough to avoid the Problem of Explanatory Shortfall faced by the source externalist. ${ }^{37}$

In short, when you have most all-things-considered reason to do one thing rather than another in a hard case, voluntarist reasons provide an additional resource with which to fill the explanatory gap left by one's externalist given reasons. In this way, hybrid voluntarism provides the resources-arguably just where they are neededfor avoiding the explanatory shortfall of source externalism. ${ }^{38}$

Hybrid voluntarism also avoids the Right Reasons Problem that plagues both pure forms of voluntarism and source internalist views. One of the difficulties with voluntarism, recall, is that it cannot block the Mafioso from willing into existence all-things-considered reasons to shoot the kneecaps off his enemy. Purely formal constraints on willing, like those suggested by Kant and his followers, are insufficient to prevent the willing of reasons willy-nilly. If, however, hybrid voluntarism is true, then voluntarism accounts for the source of only our voluntarist reasons. And since will-based reasons cannot change the valence established by one's given-source externalist-reasons, the Mafioso is unable to create the

\footnotetext{
${ }^{36}$ Here I assume that the view of value as 'precise' - admitting of cardinal representation by the reals (or utility functions mapping value onto the reals) is a nonstarter and so the second condition for the existence of voluntarist reasons is very broadly satisfied. See also n. 12.

37 There are two more possibilities that I should mention for completeness. In some hard cases, it may not be true that one has most reason to do one thing rather than another. This can be either because one's given reasons are in equipoise and the agent has failed to exercise her normative power to put her agency behind certain considerations and not others, or because she has and her all-things-considered reasonsvoluntarist and given-are in equipoise. The former raises no challenge of explanatory shortfall because all normative resources have not yet been expended; the latter depends on a substantive theory of how given and voluntarist reasons interact such that all-things-considered equipoise is more prevalent than a reasonable theory would allow. Even if such radical underdetermination of one's given and voluntarist reasons were rife, that would not detract from the interest of voluntarist reasons, assuming that there are some.

38 Note that the explanation that hybrid voluntarism makes possible is normative. The Problem of Explanatory Shortfall is a problem of shortfall in normative explanation-we run out of reasons too soon if source externalism is true. Hybrid voluntarism provides additional normative resources-voluntarist reasons-in the normative explanation of why you have most reason to $\mathrm{x}$ rather than $\mathrm{y}$.
} 
reasons that make it permissible for him to shoot the kneecaps off his enemy. This is because he has all-things-considered most given reasons not to do so, and his willbased reasons cannot change the valence established by these reasons. Of course, according to hybrid voluntarism, the Mafioso may have more reason to shoot the kneecaps off his enemy if he has created a voluntarist reason than if he had not created such a reason. But since reasons can be regarded as cheap-there might, arguably, not be much difference in there being a reason that cannot change the valence and there being no reason at all-this is arguably as it should be. ${ }^{39}$

Finally, hybrid voluntarism sidesteps the Regress Problem. The Regress Problem maintains that in order to answer the open question, 'What reason does a rational agent have to will a principle of action?, the voluntarist must either appeal to resources beyond voluntarist reasons or be faced with an endless regress of willings.

To see how the hybrid view escapes the Regress Problem, consider the following scenario. Suppose you are faced with a choice between $\mathrm{x}$ and $\mathrm{y}$, and your given reasons for choosing either have run out. According to the hybrid view, you have the normative power to create a new voluntarist reason through some act of will, which may then give you most all-things-considered reason to choose $\mathrm{x}$ over $\mathrm{y}$. Now if we ask, "What reason do you have to exercise your normative power, that is, to will a voluntarist reason as opposed to, say, employ the decision procedure 'eeny, meany, miney moe....' or toss a coin between them?' we can appeal to given reasons. You might have a given reason to will a voluntarist reason because it's a good thing to exert one's agency in making it true that one has most reason to do things. Or you could have a given reason to exercise your will in order to achieve control over what you have most reason to do instead of leaving your reasons to the vagaries of a coin toss. There are many other possible given reasons that justify the activity of creating voluntarist reasons. ${ }^{40}$ Because hybrid voluntarism does not attempt to make willing the source of all of practical normativity, it can allow that given reasons are deployed in answer to the question, 'Why go in for the activity of creating voluntarist reasons?'. These additional resources-given reasons-block the Regress Problem faced by standard forms of voluntarism. So while the question, 'What reason does one have to create a voluntarist reason?' is open, hybrid voluntarism has the resources to answer it.

There is another regress lurking in the area. We might ask, what reason is there to will this rather than that to be a voluntarist reason? Creating voluntarist reasons is something rational agents simply do, and by definition this activity of creating voluntarist reasons is not itself guided by reasons, given or otherwise. It is in the very nature of creating voluntarist reasons that doing so is not guided by reasons. This has an important implication. If the activity of willing reasons is not open to being guided by reasons, then it makes no sense to ask, 'What reason is there to will this rather than that to be a reason?' Put another way, when your given reasons run out, your willing reasons to $\mathrm{x}$ instead of $\mathrm{y}$ (or vice versa), while open to assessment

\footnotetext{
39 The importance of voluntarist reasons in cases where there is indeterminate most reason to do one thing rather than another is a complicated matter that I cannot go into here. In brief: they have little significance within a choice situation but great significance for what they suggest for the agent's 'rational identity' over time.

${ }^{40}$ I broach some in Chang 2009.
} 
by given reasons, cannot itself be guided by given reasons. ${ }^{41}$ Which reasons you will, then, is quite literally up to you.

Note that hybrid voluntarism's ability to dodge the regress cannot be transferred over to the constitutivist accounts favored by 'pure' voluntarists, such as Korsgaard. The hybrid voluntarist says that it is constitutive of the activity of willing reasons that this activity is not guided by reasons, and the pure voluntarist says it is constitutive of action itself (or of agency or of rational agency) that one's will be guided by certain requirements. Why is one view subject to regress and the other not?

In the former case, it makes no sense to ask of an activity that is by its nature not governed by reasons what reason one has to engage in that activity in one way rather than another. But it does make sense to ask of an activity that is by its nature governed by certain requirements - by hypothesis, action itself - what reasons we might have to engage in that activity (or indeed to engage in it one way rather than another). Put another way, our concept of a normative practical reason applies to action: 'what reason is there to perform actions?' makes sense, even if we can't help but act, but it does not apply to the activity of willing this rather than that to be a reason: 'what reason is there to will this rather than that to be a reason?' does not make sense. This is because asking what reason we have to will this rather than that is, in this one respect, like asking what reason we have to flinch rather than laugh when we are startledone's reaction to being startled is by its nature an activity not guided by reasons. Of course flinching is arguably not an intentional action but a reflex while willing is something that one does intentionally, perhaps for a given reason. But while there may be given reasons to engage in an act of willing, what one wills is not a matter guided by reason. Since willing this rather than that to be a reason is by its nature not something guided by reasons but simply something one does, there is no regress.

\section{Conclusion}

My aim here has been to sketch an alternative view about the sources of practical normativity and to show how, by going hybrid, we can avoid some of the main

\footnotetext{
${ }^{41}$ Strictly speaking, there are three qualifications to this claim that require further discussion beyond the scope of this paper. First, the question the activity of willing this rather than that is open to third-party assessment by reasons. When you will a voluntarist reason in favor of $\mathrm{x}$ instead of $\mathrm{y}$, your willing is not guided by given reasons. But a third party observing you can sensibly say, "She had more reason to will a reason in favor of $y$ than one in favor of $x$ ". The interpretation of these third-party statements turns on substantive claims about what makes for a unified agent and about which "rational identities" are better than others from a third-person's particular deliberative point of view. Second, there could be given instrumental reasons to will one way rather than another that may 'guide' my willing. If you offer me a hundred dollars to will a reason in favor of $\mathrm{x}$, I have a given instrumental reason to so will. (I owe this point to Daniel Nolan). But, again, these instrumental reasons do not 'guide' the activity of wiling on the merits and so do not impugn the claim that taking something to be a reason is not guided by given reasons in the sense that threatens a regress. Finally, there may be constraints derived from what it is to be a unified agent that further constrain whether one can, as a rational agent, will this rather than that. So for example the unity of agency may block the rationality of willing this $1 \mathrm{~min}$ and that the next minute, and so on, until one's death. But this last constraint will not take the form of reasons that guide one's willing one thing rather than another; rather it is a formal constraint on what it is to be an agent in the first placeto be an agent you have to be capable of getting at least some things done-and so the sense in which the question is open is different.
} 
difficulties that plague more familiar ways of grounding practical reasons. My aim has also been to try to bolster and reinvigorate the relatively neglected view that willing can be a ground of normativity. Many philosophers have dismissed the view as absurd, and it has few contemporary adherents. My suggestion in this paper is that if willing can be a ground of normativity, then it might plausibly be a ground in the way hybrid voluntarism suggests.

Acknowledgments Many thanks to Kate Manne and Julia Markovitz for excellent commentary at the Bellingham Summer Philosophy Conference where this paper was presented, and to the audience at the conference for a hybrid of entertaining and probing questions. Thanks are also due to Mary Clayton Coleman, Adam Elga, Kit Fine, Zachary Irving, Andrew Israelsen, Patrick Kain, Karin Nisenbaum, Derek Parfit, Juan Pineros, Luke Roelofs, Tina Rulli, and Jessica Wilson for useful discussion and more generally to audiences at the University of Toronto, the Murphy Institute at Tulane, and Purdue for useful feedback.

\section{References}

Antosh, M. Rutgers, Ph.D. dissertation. Draft (Manuscript).

Chang, R. (2002). The possibility of parity. Ethics, 112, 659-688.

Chang, R. (2009). Voluntarist reasons and the sources of normativity. In Sobel \& Wall (Eds.), Practical Reason and Action. Cambridge: Cambridge University Press.

Chang, R. (2012). Are hard choices cases of incomparability? Philosophical Issues, 22(1), 106-126.

Chang, R. (2013a). Commitment, reasons, and the will, Oxford Studies in Metaethics 8.

Chang, R. (2013b). Practical reasons: The problem of gridlock. In B. Dainton \& H. Robinson (Eds.), Companion to Analytical Philosophy. New York: Continuum Press.

Chang, R. Do We Have Normative Powers? Draft, (Manuscript).

Clarke, S. (1706/1969). Discourse Concerning the Unchangeable Obligations of Natural Religion, and the Truth and Certainty of the Christian Revelation. In D.D. Raphael (Ed.), British Moralists: 1650-1800 (Vol. 1, pp. 224-261). Indianapolis: Hackett.

Coleman, M. C. Exploring Meta-Normative Constitutivism, (Manuscript).

Dancy, J. (2004). Ethics without principles. Oxford: Clarendon Press.

Enoch, D. (2006). Agency, Shmagency: Why normativity won't come from what is constitutive of agency. Philosophical Review, 115, 169-198.

Enoch, D. (2011). Giving practical reasons. Philosophers' Imprint, 11(4), 1-21.

Fine, K. (2001). The question of realism. Philosophers' Imprint, 1(1), 1-30.

Fitzpatrick, W. (2005). The practical turn in ethical theory: Korsgaard's constructivism, realism, and the nature of normativity. Ethics, 115(4), 651-691.

Hill, Thomas. (1991). Autonomy and self-respect. Cambridge: Cambridge University Press.

Koch, F. (2012). Voluntarism and Reflection. Ph.D Dissertation, Columbia.

Kolodny, N. (2005). Why be rational? Mind, 114, 509-563.

Korsgaard, C. (1996). The sources of normativity. Cambridge: Cambridge University Press.

Korsgaard, C. (2003). Realism and constructivism in 20th century moral philosophy. Journal of Philosophical Research, 28, 99-122.

Korsgaard, C. (2008). The constitution of agency: Essays on practical reason and moral psychology. Oxford: Oxford University Press.

Korsgaard, C. (2009). Self-constitution: Agency, identity, and integrity. Oxford: Oxford University Press. MacCormick, N. (1972). Voluntary obligations and normative powers. Proceedings of the Aristotelian Society, Suppl. 46, 59-78.

Manne, K. How desires might matter: The veto power view. Draft, (Manuscript).

Markovits, J. (2013). Moral reason. Oxford: Oxford University Press.

Nichols, S. (2007). Sentimental rules. Oxford: Oxford University Press.

Parfit, D. (2011). On what matters. Oxford: Oxford University Press.

Parfit, D. On How to Avoid the Repugnant Conclusion, Draft, (Manuscript).

Railton, P. (2004). How to engage reason: The problem of regress. In Wallace et al. (Eds.), Reasons and values: Themes from the philosophy of Joseph Raz. Oxford: Oxford University Press. 
Railton, P. (Eds.). Toward a Unified Account of Rational Belief and Desire, Forthcoming (Manuscript). Raz, J. (1972). Voluntary obligations and normative powers. Proceedings of the Aristotelian Society, Suppl. 46, 79-102.

Raz, J. (1975). Practical reason and norms. London: Hutchinson.

Raz, J. (1999). Engaging reason: On the theory of value and action. Oxford: Oxford University Press.

Raz, J. (2005). The myth of instrumental rationality. Journal of Ethics and Social Philosophy, 1(1), 1-28.

Raz, J. (2011). From normativity to responsibility. Oxford: Oxford University Press.

Rosen, G. (2010). Metaphysical dependence: Grounding and reduction. In B. Hale \& A. Hoffman (Eds.), Modality: Metaphysics, logic \& epistemology. Oxford: Oxford University Press.

Ryle, G. (1949). The concept of mind. London: Hutchinson \& Company.

Scanlon, T. (1998). What we owe to each other. Cambridge, MA: Belknap Press.

Scanlon, T. (2003). Metaphysics and morals. Proceedings and Addresses of the American Philosophical Association, 77, 7-22.

Scanlon, T. (2004). Reasons: A puzzling duality? In Wallace, et al. (Eds.), Reason and Value: Themes form the Moral Philosophy of Joseph Raz (pp. 231-246). Oxford: Oxford University Press.

Schneewind, J. (1998). The invention of autonomy. New York: Cambridge University Press.

Shafir, E., Simonson, I., \& Tversky, A. (1993). Reason-based choice. Cognition, 49, 11-36.

Street, S. (2009). In defense of future tuesday indifference: Ideally coherent eccentrics and the contingency of what matters. Philosophical Issues, 19, 273-298.

Thomson, J. J. (2008). Normativity. New York: Open Court.

Tiberius, V. (2000). Humean heroism: Value commitments and the source of normativity. Pacific Philosophical Quarterly, 18(4), 426-446.

Tiberius, V. (2008). The reflective life: Living wisely with our limits. Oxford: Oxford University Press.

Verbeek, B. A Limited Vindication of Voluntarism in Practical Reason, (Manuscript). 